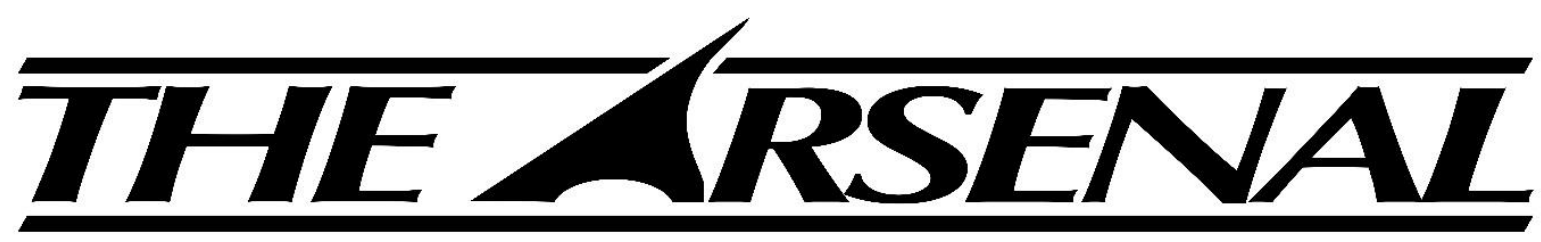

Augusta University's Undergraduate Research Journal

ISSN 2380-5064 | The Arsenal is published by the Augusta University Libraries | http://guides.augusta.edu/arsenal

Volume 4, Issue 1 (2021)

Special Edition Issue

DOES THE PRESENCE OF A USG INSTITUTION

IMPACT ECONOMIC VARIABLES WITHIN

GEORGIA METROPOLITAN STATISTICAL AREAS?

Megan Tychsen and Simon Medcalfe

\title{
Citation
}

Tychsen, M., \& Medcalfe, S. (2021). Does the presence of a USG institution impact economic variables within Georgia metropolitan statistical areas? The Arsenal: The Undergraduate Research Journal of Augusta University, 4(1), 39.

http://doi.org/10.21633/issn.2380.5064/s.2021.04.01.39

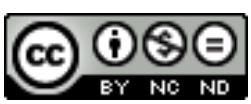

C Tychsen and Medcalfe 2021. This open access article is distributed under a Creative Commons Attribution NonCommercial-NoDerivs 2.0 Generic License (https://creativecommons.org/licenses/by-nc-nd/2.0/). 


\section{Does the Presence of a USG Institution Impact Economic Variables within Georgia Metropolitan Statistical Areas?}

Presenter(s): Megan Tychsen

Author(s): Megan Tychsen and Simon Medcalfe

Faculty Sponsor(s): Simon Medcalfe, $\mathrm{PhD}$

Affiliation(s): Hull College of Business (Augusta Univ.)

\section{ABSTRACT}

It is logical to assume that higher education institutions such as universities and colleges are beneficial to the economy, more specifically the local economy in which they are located. However, the question of whether they have a definite positive impact on local economic and demographic variables, and what potentially drives that impact, is still largely unknown. This research will analyze whether the presence of a University System of Georgia (USG) institution within a Georgia Metropolitan Statistical Area (MSA) impacts local Gross Domestic Product (GDP), unemployment rate, and population measures. Data about local MSA GDP, unemployment, and population for this research has been gathered from the Federal Reserve Economic Data (FRED) for 2011 to 2020, and data about student populations was found in USG enrollment reports for each fall enrollment period from 2011 to 2020. Preliminary results from this study indicate that consolidation of USG schools and the presence of a research institution within a MSA have had a positive impact on local unemployment rates and population numbers respectfully. Being aware of the economic impact of our USG institutions can aid in understanding how to leverage these resources to improve our local economic performance.

Received: 02/15/2021 Accepted: 03/30/2021

Correspondence: Megan Tychsen, Augusta University, $112015^{\text {th }}$ St. Augusta, GA 30912, mtchsen@augusta.edu 